\title{
Dendrometric Analysis of Early Development of Eucalyptus urophylla x Eucalyptus grandis with Gypsum use Under Subtropical Conditions
}

\author{
Carla Fernanda Ferreira ${ }^{1}$, Marcos Vinicius Martins Bassaco ${ }^{2}$ (D), Milena Pereira ${ }^{3}$, \\ Volnei Pauletti ${ }^{3}$, Stephen Arthur Prior ${ }^{4}$ (D), Antonio Carlos Vargas Motta ${ }^{3}$ \\ ${ }^{1}$ Departamento de Agronomia, Centro de Ensino Superior dos Campos Gerais - CESCAGE, Ponta Grossa/PR, Brasil \\ ${ }^{2}$ Departamento de Engenharia Florestal, Faculdades FATI-FAJAR, Jaguariaíva/PR, Brasil \\ ${ }^{3}$ Departamento de Solos e Engenharia Agrícola, Universidade Federal do Paraná - UFPR, Curitiba/PR, Brasil \\ ${ }^{4}$ ARS National Soil Dynamics Laboratory, Auburn, USA
}

\begin{abstract}
Gypsum can be used as a source for calcium (Ca) and sulphurum (S) for plants, as well as an acid, that is, a natural soil conditioner. Aiming to determine the influence of gypsum on the development of Eucalyptus urograndis in Brazil, an experiment was conducted at two locations in Paraná State. Experiments were conducted with rates of 0, 0.3, 0.6, 1.2, 2.4, 4.8 and 9.6 $\mathrm{Mg} \mathrm{ha}^{-1}$ to verify the method of broadcast planting in a randomized block design with four repetitions. Diameter and height of plants were measured every six months and volume was determined after 36 months. There was a difference in Eucalyptus growth between the two areas, possibly related to differences in planting season and climate. Gypsum did not influence on the dendrometric growth of Eucalyptus trees. The lack of a response to gypsum, as a source of $\mathrm{Ca}, \mathrm{S}$ and soil conditioner, was discussed based on soil type, Eucalyptus tolerance to soil acidity, and climatic conditions in the period evaluated.
\end{abstract}

Keywords: soil conditioner, Eucalyptus forest, dystrophic oxisol. 


\section{INTRODUCTION}

Gypsum is a known source of calcium (Ca) and sulphurum (S) for plants, and from 200 to $300 \mathrm{~kg} \mathrm{ha}^{-1}$ is sufficient to meet annual requirements of most agricultural crops (Sousa et al., 2007). Gypsum can increase $\mathrm{Ca}$ and sulphate $\left(\mathrm{SO}_{4}^{-2}\right)$ availabilities within surface and subsurface soil layers when applied at high rates (Rentería-Villalobos et al., 2010) and it could be noted that gypsum has also diminished aluminium (Al) toxicity in these soil layers without changing soil pH (Araújo et al., 2016; Nascimento et al., 2017). Thus, gypsum can be considered a good source of $\mathrm{Ca}$ and $\mathrm{S}$, and also able to alleviate aluminium (Al) toxicity in soils.

Soil chemical characteristics can influence the effectiveness of gypsum applications. Low soil availability of $\mathrm{Ca}$ and $\mathrm{S}$ nutrients can enhance plant responses to gypsum (Rocha et al., 2008; Marques et al., 2016). High toxic levels of $\mathrm{Al}$ and low levels of available $\mathrm{Ca}$ in subsurface soil layers are major factors regarding gypsum recommendations (Costa \& Crusciol, 2016; Amaral et al., 2017). However, issues concerning these soil conditions, the crop yield responses to gypsum application varies from large (Wulff-Zottele et al., 2014; Marques et al., 2016) to small (Pauletti et al., 2014), or has no change (Gelain et al.; 2011; Moda et al., 2013).

Weather conditions during crop growth, especially in relation to soil water availability, can influence response to gypsum applications (Zandoná et al., 2015). Provided that gypsum can enhance root growth in subsurface soil layers, by decreasing $\mathrm{Al}$ toxicity and increasing $\mathrm{Ca}$ availability, Water Absorption Capacity (WAC) may be expanded (Carducci et al., 2015; Freitas et al., 2015). For this reason, positive growth response to gypsum applications may occur under drought conditions (Pauletti et al., 2014; Vitti et al., 2015).

Determining the ideal gypsum rate that optimizes yield and addresses $\mathrm{Ca}$ and $\mathrm{S}$ nutritional imbalance has been the focus of previous research (Moda et al., 2013). While the application of $12 \mathrm{Mg} \mathrm{Ca} \mathrm{ha}^{-1}$ decreased growth of soybeans displaying symptoms of $\mathrm{Mg}$ deficiency (Pauletti et al., 2014), several other studies reported no decreases in productivity using similar or higher rates (Ernani et al., 2001; Gelain et al., 2011). Under greenhouse conditions, Jackson et al. (2000) reported increased growth of E. marginata D. Don ex
Sm seedlings by using gypsum in nutrient solution. Gypsum applied with B has also been shown to stimulate growth of E. citriodora Hook seedlings, when this species grows in a container (Christo \& Santos, 1990); however, the opposite was reported by Gabriel et al. (2018) when testing five rates of gypsum on Eucalyptus seedlings cultivated in pots. Under field conditions, Rodrigues et al. (2016) observed a large increase in Eucalyptus trunk size with applications of limestone and gypsum $\left(1 \mathrm{Mg} \mathrm{ha}^{-1}\right)$ alone, or in combination of these nutrients. Macana (2017) reported that gypsum (1.2 $\left.\mathrm{Mg} \mathrm{ha}^{-1}\right)$ did not change E. urophylla S. T. Blake tree volume measurements, but increased timber (biomass) as a result of enhanced tissue density at 38 months.

The few studies that have evaluated the effects of gypsum on Eucalyptus, under field conditions, have only compared gypsum (compared to no gypsum) at rates below those used in grain crop tests. Thus, technical information on the effectiveness of using gypsum in Eucalyptus forest systems as a nutrient source and/or soil conditioner is limited. Furthermore, there are few existing studies that have been developed under tropical conditions with periods of water deficit. Our experiment was implemented in a subtropical environment with no dry season and evaluated the effects of a wide range of gypsum rates on growth parameters of $E$. urograndis.

\section{MATERIAL AND METHODS}

Eucalyptus urograndis is a hybrid of E. urophylla and E. grandis. Under subtropical conditions regarding Brazilian territory, E. urograndis was cultivated in Paraná State, in two municipalities (Jaguariaíva and Ventania) that are located in the second plateau of Paraná. The municipality of Jaguariaíva is situated at $24^{\circ} 15^{\prime} 04^{\prime \prime}$ S latitude, 49²' $21^{\prime \prime}$ W longitude, and has an elevation of $926 \mathrm{~m}$. The climate type $\mathrm{Cfb}$ (temperate, humid mesothermal with warm summer) was based on the Köppen classification system (Alvares et al., 2013). The Geographic Coordinate System (GCS) of Ventania is on $24^{\circ} 14^{\prime} 45^{\prime \prime}$ S latitude, $50^{\circ} 14^{\prime} 34^{\prime \prime} \mathrm{W}$ longitude, has an elevation of $718 \mathrm{~m}$, and climate is characterized by transition from $\mathrm{Cfb}$ to $\mathrm{Cfa}$ (humid subtropical climate), with hot summers (Alvares et al., 2013).

Air temperature and rainfall data were obtained from meteorological stations near the experimental areas. Meteorological monitoring occurred from 
December 2013 to December 2016 at Jaguariaíva, and from April 2014 to April 2017 at Ventania (Figure 1). The cumulative rainfall for the first 36 months was $8,500 \mathrm{~mm}$ for Jaguariaíva, which precipitation was higher when compared to Ventania $(6,000 \mathrm{~mm})$.

The composition of native vegetation of the Jaguariaíva region was consisted of a variability of two biomes from Southern Brazil, savanna vegetation (a small fragment of Cerrado) and Mixed Ombrophilous Forest (MOF). The composition of native vegetation of Ventania was MOF. The two experimental areas had previously been cultivated with Pinus spp. during a period of two cycles of 18 years each.

In this region, the geology could be characterized as sandstones, sedimentary rocks (Paleozoic period). Soils were classified as Dystrophic Oxisols with medium-textured soil (sandy loam). Prior to planting, soil samples were collected $(0-0.20 \mathrm{~m}, 0.20-0.40 \mathrm{~m}$, and $0.40-0.60 \mathrm{~m}$ depths) for initial characterization. Samples were air-dried, homogenized, and passed through a $2 \mathrm{~mm}$ screen mesh for analysis of $\mathrm{pH}, \mathrm{Ca}^{2+}, \mathrm{Mg}^{2+}, \mathrm{Al}^{+3}$ (extracted with $\mathrm{KCl} 1 \mathrm{M}$ ), $\mathrm{K}^{+}$, and for measuring

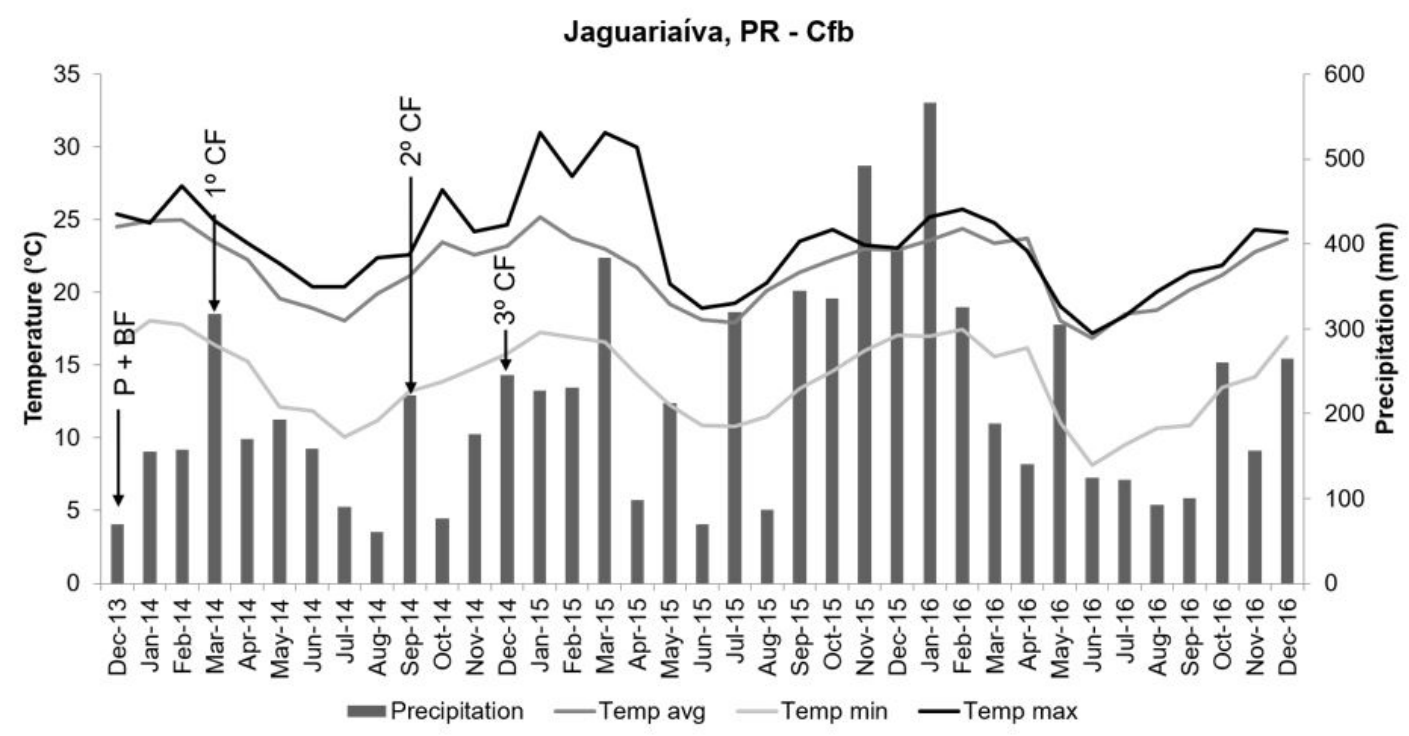

Ventania, PR - Cfa

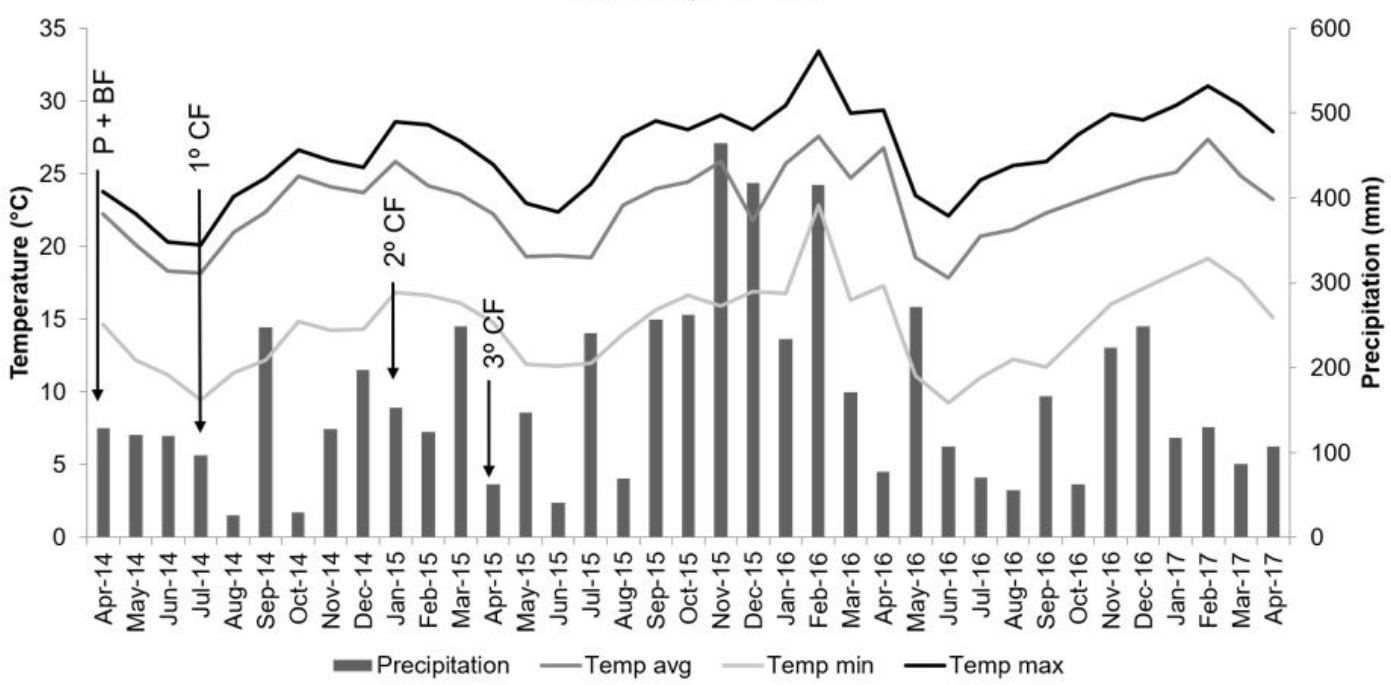

Figure 1. Minimum temperature (Temp $\mathrm{min}$ ), average temperature (Temp avg), maximum temperature (Temp max), and precipitation over 36 months at Jaguariaíva and Ventania, Paraná State, Brazil. Planting (P); Base Fertilization (BF); $1^{\circ}, 2^{\circ}$, and $3^{\circ}$ side-dress fertilizations (CF). 
extractable phosphorus (P) by P-Mehlich I. Table 1 shows soil chemical characteristics before performing experiments at both locations.

Seven gypsum rates were used as treatments $\left(0,0.3,0.6,1.2,2.4,4.8\right.$, and $\left.9.6 \mathrm{Mgha}^{-1}\right)$. The experimental design was the Randomized Complete Block Design (RCBD) with four replications (28 total plots). Gypsum was obtained from phosphate fertilizer production with Ca content of $19.31 \%$ and S content of $15.83 \%$. Gypsum broadcast on the soil surface took place when tree seedlings were being transplanted. The total experimental area was $16,128 \mathrm{~m}^{2}$ and each treatment plot was $24 \mathrm{~m} \mathrm{x} 24 \mathrm{~m}\left(576 \mathrm{~m}^{2}\right)$. Eucalyptus urograndis (clone AEC 224$)$ seedlings ( $15-20 \mathrm{~cm}$ height) were transplanted at a spacing of $3 \times 3 \mathrm{~m}$ (between plants and rows); there were a total of 64 plants per plot (8 x 8 plants).

Before transplanting, it was applied $2 \mathrm{Mg} \mathrm{ha}^{-1}$ of dolomitic limestone (effective calcium carbonate equivalent $=82 \%$ ) onto the soil surface. In addition, $200 \mathrm{~kg} \mathrm{ha}^{-1}$ of reactive natural phosphate $\left(29 \% \mathrm{P}_{2} \mathrm{O}_{5}\right)$ was applied during subsoiling ( $45 \mathrm{~cm}$ depth). After transplanting, an initial application of Nitrogen/Phosphorus/Potassium (NPK) fertilizer added $8.5 \mathrm{~kg} \mathrm{ha}^{-1}$ of $\mathrm{N}, 51 \mathrm{~kg} \mathrm{ha}^{-1}$ of $\mathrm{P}_{2} \mathrm{O}_{5}$, and $17 \mathrm{~kg} \mathrm{ha}^{-1}$ of $\mathrm{K}_{2} \mathrm{O}$. After three, nine and 12 months of transplanting, side dressings (both sides of seedlings) were applied at rates of $24 \mathrm{~kg} \mathrm{~N} \mathrm{ha}^{-1}, 8 \mathrm{~kg} \mathrm{P}_{2} \mathrm{O}_{5} \mathrm{ha}^{-1}$, $48 \mathrm{~kg} \mathrm{~K}_{2} \mathrm{O} \mathrm{ha}{ }^{-1}$, and $0.8 \mathrm{~kg} \mathrm{~B} \mathrm{ha}^{-1}$. The compouds of the side dressing sources were urea $\left(\mathrm{CH}_{4} \mathrm{~N}_{2} \mathrm{O}\right)$, triple superphosphate (TSP) $\left(\mathrm{P}_{2} \mathrm{O}_{5}\right)$, potassium chloride $(\mathrm{KCl})$ and boric acid $\left(\mathrm{H}_{3} \mathrm{BO}_{3}\right)$.

Tree assessments included height, Diameter at the Tree Base (DTB), Diameter at Breast Height (DBH) and tree volume. Initial tree height was measured using a standard graduated ruler. The height assessments employed after the initial one used the Haglöf Electronic Clinometer (HEC); 36 centrally located trees $(6 \times 6)$ were measured at three, six, nine, 12, 24, 30, and 36 months after transplanting. The DTB was measured at three and six months at both locations. The $\mathrm{DBH}$ was measured using a standard flexible measuring tape in other months. At 36 months, an average size tree was cut (based on $\mathrm{DBH}$ ) and volume was calculated using the Hohenald method. Diameters were measured at the trunk base and at points located at 25, 50, 75 and 100\% of total trunk length. Using these measurements, the individual tree volume $\left(\mathrm{m}^{3}\right)$ was determined using the shape function with an adjustment value of 0.33 . For calculations of total volume $\left(\mathrm{m}^{3} \mathrm{ha}^{-1}\right)$, the mortality rate was disregarded.

Results were submitted to analysis of variance (ANOVA). Averages were compared by regression analysis (Software ASSISTAT) and probability levels were $1 \%(\mathrm{p} \leq 0.01)$ or $5 \%(\mathrm{p} \leq 0.05)$.

\section{RESULTS}

Tree heights over the 36 month study period can be seen in Table 2. Gypsum affected tree height at Ventania area only at 30 months, with a linear increase $[\mathrm{y}(\mathrm{m})=15.50+0.082 \mathrm{x}$ at Ventania]. However, this positive response was not observed at 36 months. There was a variation in tree heights at 36 months, in other words, $2.00 \mathrm{~m}$ variation $(16.4-18.4 \mathrm{~m})$ at Jaguariaíva area, and $1.40 \mathrm{~m}$ variation at Ventania area (18.1 - $19.5 \mathrm{~m}$ ). At Jaguariaíva area, the average overall

Table 1. Soil chemical characteristics before initiation of studies at Jaguariaíva and Ventania, Paraná State, Brazil.

\begin{tabular}{|c|c|c|c|c|c|c|c|c|c|c|c|c|c|}
\hline Depth & \multirow{2}{*}{$\begin{array}{c}\mathrm{pH}^{1} \\
\mathrm{CaCl}_{2}\end{array}$} & \multirow{2}{*}{$\begin{array}{c}\mathbf{p H}^{2} \\
\text { SMP }\end{array}$} & $\mathbf{A l}^{3+}$ & $\mathbf{H}+\mathbf{A} \mathbf{l}^{*}$ & $\mathrm{Ca}^{2+}$ & $\mathbf{M g}^{2+}$ & $\mathbf{K}^{+}$ & $\mathbf{B S}^{3}$ & $\begin{array}{c}\mathrm{CEC}^{4} \\
\mathrm{pH} 7.0 \\
\end{array}$ & \multirow{2}{*}{$\frac{P}{\mathrm{mgdm^{-3 }}}$} & \multirow{2}{*}{$\frac{C_{\text {org }}}{\mathrm{g} \mathrm{dm}^{-3}}$} & \multicolumn{2}{|l|}{$\mathbf{V}^{5}$} \\
\hline $\mathbf{m}$ & & & \multicolumn{7}{|c|}{ 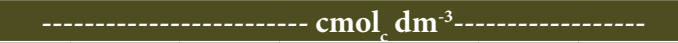 } & & & \multicolumn{2}{|c|}{---- \% ---- } \\
\hline \multicolumn{14}{|c|}{ Jaguariaíva } \\
\hline $0.00-0.20$ & 3.9 & 5.7 & 1.5 & 6.4 & 0.2 & 0.2 & 0.02 & 0.42 & 6.82 & 1.0 & 23.6 & 6.15 & 78.12 \\
\hline $0.20-0.40$ & 3.8 & 5.9 & 1.2 & 2.2 & 0.1 & 0.1 & 0.02 & 0.22 & 2.42 & 0.7 & 16.1 & 9.09 & 84.50 \\
\hline $0.40-0.60$ & 4.0 & 6.1 & 1.0 & 4.6 & 0.1 & 0.1 & 0.01 & 0.21 & 4.81 & 0.6 & 17.4 & 4.36 & 82.64 \\
\hline \multicolumn{14}{|c|}{ Ventania } \\
\hline $0.00-0.20$ & 4.3 & 6.2 & 1.5 & 4.3 & 0.1 & 0.1 & 0.03 & 0.23 & 4.53 & 2.2 & 21.0 & 5.08 & 86.71 \\
\hline $0.20-0.40$ & 4.5 & 6.7 & 1.1 & 3.0 & 0.1 & 0.1 & 0.03 & 0.23 & 3.23 & 1.6 & 11.0 & 7.12 & 82.70 \\
\hline $0.40-0.60$ & 4.4 & 6.8 & 1.2 & 2.7 & 0.1 & 0.1 & 0.03 & 0.23 & 2.93 & 0.4 & 7.3 & 7.84 & 83.91 \\
\hline
\end{tabular}

${ }^{1} \mathrm{pH} \mathrm{CaCl}=$ soil/ $\mathrm{CaCl}_{2}$ ratio 1: $2.5 ;{ }^{2} \mathrm{pH}_{\mathrm{SMP}}=\mathrm{SMP}$ buffer solution (Schumaker, Mc Lean and Pratney); ${ }^{3} \mathrm{BS}=$ base sum $(\mathrm{Ca}+\mathrm{Mg}+\mathrm{K}) ;$ ${ }^{4} \mathrm{CEC}=$ Cation Exchange Capacity; ${ }^{5} \mathrm{~V}=$ base saturation of CEC (Cation Exchange Capacity); ${ }^{6} \mathrm{~m}=$ saturation by aluminum; ${ }^{*} \mathrm{H}+\mathrm{Al}$ extraction acetate $\mathrm{Ca}\left(0.5 \mathrm{~mol} \mathrm{~L}^{-1}\right) ; \mathrm{Al}, \mathrm{Ca}$ and $\mathrm{Mg}$ extraction $\mathrm{KCl}\left(1 \mathrm{~mol} \mathrm{~L}^{-1}\right) 1 \mathrm{~N} ; \mathrm{K}$ and P extraction Mehlich I; C - organic carbon (volumetric method potassium dichromate). 
height increase was $5.8,6.7$, and $4.9 \mathrm{~m}$ in the first, second, and third year, respectively, while respective values for Ventania were 7.5, 5.8, and $3.1 \mathrm{~m}$.
Assessments of DTB at three and six months showed no influence of gypsum treatments at both sites (Table 3); similarly, gypsum application had no effect

Table 2. Height of the Eucalyptus hybrid E. urograndis at 3, 6, 9, 12, 24, 30, and 36 months after gypsum applications $\left(0,0.3,0.6,1.2,2.4,4.8\right.$, and $\left.9.6 \mathrm{Mg} \mathrm{ha}^{-1}\right)$ at Jaguariaíva (a) and Ventania (b), Paraná State, Brazil.

\begin{tabular}{|c|c|c|c|c|c|c|c|}
\hline Gypsum & \multicolumn{7}{|c|}{ Age (months) } \\
\hline Rate & 3 & 6 & 9 & 12 & 24 & 30 & 36 \\
\hline $\mathrm{Mg} \mathrm{ha}^{-1}$ & \multicolumn{7}{|c|}{ 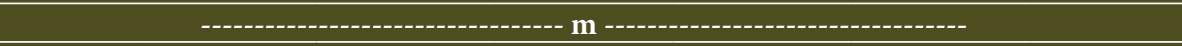 } \\
\hline \multicolumn{8}{|c|}{ (a) } \\
\hline 0 & 0.81 & 2.49 & 4.17 & 5.79 & 11.97 & 14.95 & 16.95 \\
\hline 0.3 & 0.86 & 2.62 & 4.72 & 5.87 & 12.40 & 14.59 & 17.58 \\
\hline 0.6 & 0.82 & 2.47 & 4.20 & 5.71 & 12.73 & 15.29 & 18.40 \\
\hline 1.2 & 0.86 & 2.66 & 4.14 & 5.98 & 12.32 & 14.72 & 17.58 \\
\hline 2.4 & 0.92 & 2.73 & 4.38 & 5.87 & 12.73 & 13.93 & 17.98 \\
\hline 4.8 & 0.92 & 2.78 & 4.46 & 5.94 & 12.91 & 14.83 & 16.40 \\
\hline 9.6 & 0.84 & 2.55 & 4.34 & 5.72 & 12.50 & 15.26 & 17.24 \\
\hline C.V. $(\%)^{1}$ & $10.11^{\text {n.s. }}$ & $7.62^{\text {n.s. }}$ & $7.28^{\text {n.s. }}$ & $2.82^{\text {n.s. }}$ & $6.06^{\text {n.s. }}$ & $6.04^{\text {n.s. }}$ & $6.13^{\text {n.s. }}$ \\
\hline \multicolumn{8}{|c|}{ (b) } \\
\hline 0 & 0.62 & 3.44 & 6.02 & 7.63 & 13.16 & 14.91 & 19.38 \\
\hline 0.3 & 0.64 & 3.44 & 6.04 & 7.26 & 13.27 & 15.73 & 18.12 \\
\hline 0.6 & 0.55 & 3.46 & 6.18 & 7.38 & 13.33 & 15.27 & 18.80 \\
\hline 1.2 & 0.58 & 3.68 & 6.01 & 7.08 & 12.68 & 15.48 & 18.98 \\
\hline 2.4 & 0.59 & 3.43 & 6.16 & 7.81 & 12.58 & 16.24 & 19.54 \\
\hline 4.8 & 0.58 & 3.40 & 6.06 & 7.58 & 14.11 & 16.69 & 18.22 \\
\hline 9.6 & 0.55 & 3.42 & 5.85 & 7.60 & 13.52 & 15.81 & 19.03 \\
\hline C.V. $(\%)^{*}$ & $7.62^{\text {n.s. }}$ & $6.24^{\text {n.s. }}$ & $3.95^{\text {n.s. }}$ & $4.05^{\text {n.s. }}$ & $5.49^{\text {n.s. }}$ & $5.39^{* *}$ & $3.87^{\text {n.s. }}$ \\
\hline
\end{tabular}

${ }^{\star} \mathrm{C} . \mathrm{V}=$ coefficient of variation; ${ }^{* *}$ significant at the $5 \%$ probability level, regression test; ${ }^{\text {n.s }}$ indicates not significant. ${ }^{1}$ represents linear regression equations, respectively.

Table 3. Diameters at the tree base (DTB) and breast height (DBH) for the Eucalyptus hybrid E. urograndis at $3,6,9,12,24,30$, and 36 months after gypsum applications $\left(0,0.3,0.6,1.2,2.4,4.8\right.$, and $\left.9.6 \mathrm{Mg} \mathrm{ha}^{-1}\right)$ at Jaguariaíva (a) and Ventania (b), Paraná State, Brazil.

\begin{tabular}{|c|c|c|c|c|c|c|c|}
\hline Gypsum & \multicolumn{7}{|c|}{ Age (months) } \\
\hline Rate & 3 & 6 & 9 & 12 & 24 & 30 & 36 \\
\hline $\mathrm{Mg} \mathrm{ha}^{-1}$ & \multicolumn{7}{|c|}{ 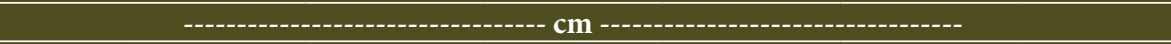 } \\
\hline (a) & DTB & DTB & DBH & DBH & DBH & DBH & DBH \\
\hline 0 & 1.41 & 4.59 & 4.44 & 6.96 & 12.99 & 14.40 & 15.90 \\
\hline 0.3 & 1.53 & 4.89 & 3.90 & 6.37 & 13.11 & 14.05 & 15.00 \\
\hline 0.6 & 1.42 & 4.64 & 4.38 & 7.34 & 13.57 & 14.76 & 15.87 \\
\hline 1.2 & 1.49 & 4.96 & 4.43 & 7.36 & 13.09 & 14.02 & 15.33 \\
\hline 2.4 & 1.67 & 4.95 & 4.70 & 7.30 & 13.21 & 14.17 & 15.21 \\
\hline 4.8 & 1.68 & 4.92 & 4.77 & 7.44 & 14.17 & 14.40 & 15.68 \\
\hline 9.6 & 1.41 & 4.66 & 4.45 & 7.19 & 13.53 & 14.80 & 15.60 \\
\hline C.V. $(\%)^{1}$ & $4.56^{\text {n.s. }}$ & $6.96^{\text {n.s. }}$ & $11.96^{\text {n.s. }}$ & $9.83^{\text {n.s. }}$ & $5.43^{\text {n.s. }}$ & $3.74^{\text {n.s. }}$ & $4.25^{\mathrm{n} . \mathrm{s}}$ \\
\hline (b) & DTB & DTB & DBH & DBH & DBH & DBH & DBH \\
\hline $\mathrm{Mg} \mathrm{ha}^{-1}$ & \multicolumn{7}{|c|}{ 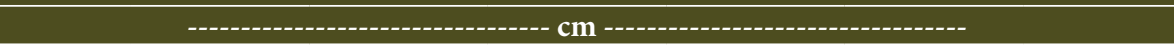 } \\
\hline 0 & 1.04 & 2.94 & 6.27 & 8.28 & 12.79 & 13.57 & 15.47 \\
\hline 0.3 & 1.07 & 2.84 & 5.96 & 8.36 & 12.75 & 13.66 & 15.32 \\
\hline 0.6 & 0.89 & 2.96 & 6.11 & 8.01 & 12.71 & 13.54 & 15.53 \\
\hline 1.2 & 0.96 & 2.86 & 6.05 & 8.40 & 12.89 & 13.62 & 15.64 \\
\hline 2.4 & 0.93 & 2.93 & 6.22 & 8.46 & 13.13 & 14.04 & 15.65 \\
\hline 4.8 & 0.98 & 2.84 & 6.09 & 8.56 & 12.88 & 13.65 & 15.51 \\
\hline 9.6 & 0.87 & 2.87 & 6.01 & 8.61 & 13.01 & 13.82 & 15.96 \\
\hline C.V. $(\%)^{*}$ & $7.93^{\text {n.s. }}$ & $9.89^{\text {n.s. }}$ & $3.69^{\text {n.s. }}$ & $3.82^{\text {n.s. }}$ & $3.55^{\text {n.s. }}$ & $3.89^{* *}$ & $3.39^{\text {n.s. }}$ \\
\hline
\end{tabular}

${ }^{\star} \mathrm{C} . \mathrm{V}=$ coefficient of variation; ${ }^{* *}$ significant at the $5 \%$ probability level, regression test; ${ }^{\text {n.s }}$ indicates not significant. ${ }^{1}$ represents linear regression equations, respectively. 
Table 4. Individual tree volume $\left(\mathrm{m}^{3}\right)$ and total tree volume $\left(\mathrm{m}^{3} \mathrm{ha}^{-1}\right)$ of Eucalyptus hybrid E. urograndis at 36 months after gypsum application $\left[0,0.3,0.6,1.2,2.4 .4 .8\right.$, and $9.6 \mathrm{Mg} \mathrm{ha}^{-1}$ ) at Jaguariaíva and Ventania, Paraná State, Brazil.

\begin{tabular}{|c|c|c|c|c|}
\hline Gypsum & \multicolumn{2}{|c|}{ Individual tree volume } & \multicolumn{2}{|c|}{ Total tree volume } \\
\hline $\mathrm{Mg} \mathrm{ha}^{-1}$ & \multicolumn{2}{|c|}{$\mathbf{m}^{3}$} & \multicolumn{2}{|c|}{$\mathbf{m}^{3} \mathbf{h a}^{-1}$} \\
\hline & Jaguariaíva & Ventania & Jaguariaíva & Ventania \\
\hline 0 & 0.11 & 0.12 & 124.22 & 133.90 \\
\hline 0.3 & 0.10 & 0.11 & 114.03 & 122.56 \\
\hline 0.6 & 0.12 & 0.12 & 134.07 & 130.44 \\
\hline 1.2 & 0.11 & 0.12 & 118.88 & 134.12 \\
\hline 2.4 & 0.11 & 0.12 & 120.05 & 137.92 \\
\hline 4.8 & 0.10 & 0.11 & 116.09 & 126.75 \\
\hline 9.6 & 0.11 & 0.13 & 121.41 & 139.74 \\
\hline C.V. $(\%)^{1}$ & $10.86^{\text {n.s. }}$ & $8.96^{\text {n.s. }}$ & $10.86^{\text {n.s. }}$ & $8.96^{\text {n.s. }}$ \\
\hline
\end{tabular}

${ }^{1} \mathrm{C} . \mathrm{V} .=$ coefficient of variation; ${ }^{\text {n.s }}$ indicates not significant.

on DBH over time. Across all treatments, higher initial growth in terms of DTB was observed at Jaguariaíva area. At three months of age, DTB at Jaguariaíva area varied from 1.41 to $1.68 \mathrm{~cm}$ compared to 0.87 to $1.07 \mathrm{~cm}$ at Ventania area. Even after six months, Jaguariaíva presented larger values of DTB compared to Ventania. Differences in both areas were maintained at nine and 12 month assessments (Ventania presented larger DBH), but similar values of DBH were observed at 24,30, and 36 months for both areas. In addition, small differences between treatments were observed at Ventania area at 30 months (first degree linear regression).

Results for individual tree volume and total volume $\left(\mathrm{m}^{3} \mathrm{ha}^{-1}\right)$ at 36 months are shown in Table 4 . As could be observed in tree height and diameter assessments, gypsum application did not affect either individual tree or total volume.

\section{DISCUSSION}

Dendrometric measures in our study generally reflect those of other Eucalyptus studies of similar age. It could be noted that tree height increases of 5,12 , and $18 \mathrm{~m}$ were reported for the first, second, and third years in São Paulo State (Brazil) for E. grandis and E. urograndis (Almeida et al., 2010; Pinheiro et al., 2016). Tree heights in our study were similar with an overall average of 6,13 , and $17 \mathrm{~m}$ at Jaguariaíva and 8,13 , and $19 \mathrm{~m}$ at Ventania for three years of study period. At three and nine months, Freitas et al. (2009) by evaluating the effects of different managements of Eucalyptus seedlings, they could find an average diameters from 2.0 to $4.5 \mathrm{~cm}$, which were similar to diameters noted at Jaguariaíva; on the other hand, at nine months diameters were smaller than Ventania. At 18 months, Rodrigues et al. (2016) reported a DBH of $\sim 8.0 \mathrm{~cm}$ for E. urograndis, closer to height parameters for Jaguariaíva area, but lower than Ventania area at 12 months. Despite these variations, tree diameters at both areas were within the range expected for this species.

In addition, mean yields of $40.3 \mathrm{~m}^{3} \mathrm{ha}^{-1}$ year ${ }^{-1}$ at Jaguariaíva and $44.0 \mathrm{~m}^{3} \mathrm{ha}^{-1}$ year ${ }^{-1}$ at Ventania were similar to the national mean (IBÁ, 2016). While their soils had somewhat similar characteristics, some edaphoclimatic characteristics can be highlighted as a variation factor: accumulated precipitation was higher at Jaguariaíva $(+1,500 \mathrm{~mm})$, while Ventania had slightly higher annual mean temperature $\left( \pm 1^{\circ} \mathrm{C}\right)$ and less annual frost. Measures of height, diameter, and yield confirmed that our study areas reflected normal productivity despite very low soil fertility under subtropical climatic conditions.

Due to the lack of a gypsum response, our findings suggest that soils were able to supply needed for $\mathrm{Ca}$ and $S$ nutrients. The absence of a response may be related to isolated or combined effects of edaphic, management, and climate factors. Eucalyptus may have a high Ca demand and has been shown to exhibit high Ca extraction capacity, primarily due to arbuscular mycorrhizal fungi (AMF) and exploration of the radicular canal of soil depth (Pinheiro et al., 2016). This capacity can even occur under very low availability conditions as could be observed in our study of these soils. In 
addition to this high capacity, it is important to note that $400 \mathrm{~kg} \mathrm{ha}^{-1}$ of Ca were added during limestone application prior to planting. Calcium was also added in smaller quantities at planting and during the three side dressings of TSP. Concerning a study on the same soil type in our region, Bizon (2005) evaluated sources of Ca nutrient in a Pinus taeda L. plantation and found that litter accumulations above $40 \mathrm{Mg} \mathrm{ha}^{-1}$ were equivalent to $80 \mathrm{~kg} \mathrm{Ca} \mathrm{ha}^{-1}$. Thus, litter from previous Pinus forest cycles was another potential Ca source that may have decreased the effect of gypsum application. A combination of the above factors (high Ca capacity, Ca from lime, fertilizer and litter) could have supplied sufficient $\mathrm{Ca}$ (350 to $450 \mathrm{~kg} \mathrm{ha}^{-1}$ ) for seven years of productivity at a rate of $50 \mathrm{~m}^{3} \mathrm{ha}^{-1}$ year-1 (Benatti, 2013).

Since no $S$ was applied by fertilization (except $~ 1 \%$ $S$ from TSP) and no gypsum response was observed, it is probable that $S$ requirements were met via the mineralization of organic S. On a dystrophic red-yellow (Oxisol) having 2\% organic matter, Rodrigues et al. (2016) observed large yield increases that were attributable to $\mathrm{S}$, in contrast to our study. Soil organic $\mathrm{C}$ levels had a concentration from medium to high at both areas (Jaguariaíva and Ventania) suggesting a $S$ reserve. About $98 \%$ of $S$ in tropical soils can be associated with organic matter (Aita \& Giacomini, 2007). In P. taeda plantations, the annual contribution from litterfall decomposition could be $1.3 \mathrm{~kg} \mathrm{~S} \mathrm{ha}^{-1}$ (Viera \& Schumacher, 2010). Thus, litter originated from antecedent Pinus cycles was a likely source of $S$ in our study. Rocha et al. (2015) reported that $S$ accumulated in soil and leaf litter (13 to $33 \mathrm{~kg} \mathrm{~S} \mathrm{a}^{-1}$ ) on Eucalyptus plantations could meet tree requirements for cycles lasting from seven to nine years. In addition, the presence of paper cellulose factories in the Jaguariaíva region implies the possibility of atmospheric S contributions.

Similar to S, organic matter can also be a major nitrogen $(\mathrm{N})$ soil reservoir. At the same locations (Bassaco et al., 2018), the absence of $\mathrm{N}$ response in Eucalyptus over three years suggested an adequate supply via Soil Organic Matter (SOM) and litter decay. In another Brazilian Eucalyptus study, adequate concentrations of $\mathrm{N}$ supplied by organic matter decomposition resulted in little or no response to applied N (Gazola et al., 2015).

Limiting characteristics of our soils (e.g., high soil acidity, toxic $\mathrm{Al}$ levels in deeper soil zones, low $\mathrm{Ca}$ in deeper soil zones) favored the use of gypsum as a soil conditioner (Nietfeld \& Prenzel, 2015). Several reasons could explain the lack of a gypsum response in our study. Firstly, the limestone application prior to study initiation may have limited soil conditioning properties of gypsum. While some researchers have reported a decreased response to gypsum when used to correct soil acidity (Rodrigues et al., 2016), others have reported that one limestone application increased Eucalyptus production (Rocha et al., 2008). Regarding the second reason, high and well distributed precipitation favored soil water availability and could have assisted the mechanism of Ca contact by mass flow. Oliva et al. (1989) observed Ca deficiency in Eucalyptus during dry periods, and the largest responses to gypsum observed by Pauletti et al. (2014) were under water deficit conditions. Third, Eucalyptus is recognized for a high tolerance to toxic $\mathrm{Al}$ levels (Rocha et al., 2008) via different mechanisms (Hartwig et al., 2007). In addition to immobilizing Al into cell walls, Echart \& Molina (2001) proposed that these plants may tolerate Al by accumulating it in the symplast and excluding it from the root apex. Such mechanisms may play a role in explaining why applications of gypsum displayed little affect.

Differences in tree height between areas were observed at 12,24, and 36 months with higher values observed at Ventania. Jaguariaíva trees were expected to be taller since they were planted four months earlier and this region had more total rainfall; however, taller heights at Jaguariaíva only persisted up to six months. Despite soil conditions similar to Jaguariaíva, Eucalyptus generally exhibited better growth at Ventania. This difference could be attributed to slightly higher air temperatures and lower altitude $( \pm 208 \mathrm{~m})$ at Ventania, since Eucalyptus has generally shown higher growth potential under more tropical conditions (Stape et al., 2010). Hybridization of E. urophylla may have resulted in the selection of factors more suitable for growth in this climate (Scanavaca \& Garcia, 2003). However, further studies should be conducted to identify which features favor optimal growth in this region.

\section{CONCLUSION}

The absence of a response to gypsum as a source of $\mathrm{Ca}$ and $\mathrm{S}$ nutrients may be related to edaphic, management and climate factors. The application of 
Ca via limestone, coupled with the high capacity of Eucalyptus to extract $\mathrm{Ca}$, could help explaining a lack of response to gypsum. Further, high organic matter and leaf litter from preceding Pinus cycles likely provided sufficient $\mathrm{S}$ amounts for Eucalyptus growth. The lack of a response to high rates of gypsum, as a soil conditioner, could also be due to a combination of factors. Limestone application prior to study initiation may have hindered a response. Probably, the abundance of water from well distributed rainfall played a role since positive responses to gypsum applications have been more pronounced under water deficit conditions. Despite a focus of using gypsum as a soil conditioner to overcome high soil Al levels, Eucalyptus has inherent physiological mechanisms to resist Al toxicity. Findings indicated some variation in area conditions that favored E. urograndis growth at Ventania.

\section{ACKNOWLEDGEMENTS}

We thank to the Florestal Vale do Corisco S.A. for the availability of the experimental areas.

\section{SUBMISSION STATUS}

Received: 10 jul., 2019

Accepted: 13 nov., 2019

\section{CORRESPONDENCE TO}

\section{Marcos Vinicius Martins Bassaco}

Rua do Funcionários, Curitiba, PR, Brasil, CEP 80060-000

e-mail: marcos.bassaco@hotmail.com

\section{FINANCIAL SUPPORT}

Conselho Nacional de Desenvolvimento Científico e Tecnológico, (R\$39.600,00/ 306.908/2016-6).

\section{REFERENCES}

Aita C, Giacomini SJ. Matéria orgânica do solo, nitrogênio e enxofre nos diversos sistemas de exploração agrícola. In: Yamada, T, Abdalla, SRS, Vitti, GC, editores. Nitrogênio e enxofre na agricultura brasileira. Piracicaba: IPNI Brasil; 2007.
Almeida JCR, Laclau JP, Goncalves JLD, Ranger J, Saintandre L. A positive growth response to $\mathrm{NaCl}$ applications in Eucalyptus plantations established on K-deficient soils. Forest Ecology and Management 2010; 259(9): 1786-1795. http://dx.doi.org/10.1016/j.foreco.2009.08.032.

Alvares CA, Stape JL, Sentelhas PC, Gonçalvez JLM, Sparovek G. Köppen's climate classification map for Brazil. Meteorologische Zeitschrift 2013; 22(6): 711-728. http:// dx.doi.org/10.1127/0941-2948/2013/0507.

Amaral LA, Ascari JP, Duarte WM, Mendes IRN, Santos ES, Julio OLL. Effect of gypsum rates in corn and chemical changes in the soil. Agrarian 2017; 10(35): 31-41. http:// dx.doi.org/10.30612/agrarian.v10i35.4139.

Araújo LC, Figueiredo CC, Souza DMG, Nunes RS, Rein TA. Influence of gypsum application on sugarcane yield and soil chemical properties in the Brazilian Cerrado. Australian Journal of Crop Science 2016; 10(11): 1557 1563. http://dx.doi.org/10.21475/ajcs.2016.10.11.PNE156.

Bassaco MVM, Motta ACV, Pauletti V, Prior SA, Nisgoski $S$, Ferreira CF. Nitrogen, phosphorus, and potassium requirements for Eucalyptus urograndis plantations in southern Brazil. New Forests 2018; 49(5): 681-697. http:// dx.doi.org/10.1007/s11056-018-9658-0.

Benatti BP. Compartimentalização de biomassa e de nutrientes em estruturas de plantas de eucalipto cultivadas em solos distintos [dissertação]. Lavras: Universidade Federal de Lavras; 2013.

Bizon JMC. Avaliação da sustentabilidade nutricional de plantios de Pinus taeda L. usando um balanço de entrada e saída de nutrientes [dissertação]. Piracicaba: Escola Superior de Agricultura Luiz de Queiroz; 2005.

Carducci CE, Oliveira GC, Oliveira LM, Barbosa SM, Silva EA. Retenção de água do solo sob sistema conservacionista de manejo com diferentes doses de gesso. Revista de Ciências Agrárias 2015; 58(3): 284-291. http://dx.doi. org/10.4322/rca.2014.

Christo SSM, Santos OS. Efeitos do gesso e do boro na produção de mudas de Eucalyptus citriodora Hook. Revista Centro de Ciências Rurais 1990; 20: 173-184.

Costa CHM, Crusciol CAC. Long-term effects of lime and phosphogypsum application on tropical no-till soybeanoat-sorghum rotation and soil chemical properties. European Journal of Agronomy 2016; 74: 119-132. http:// dx.doi.org/10.1016/j.eja.2015.12.001.

Echart CL, Molina SC. Aluminum phytotoxicity: effects, tolerance mechanisms and its genetic control. Ciência Rural 2001; 31(3): 531-541. http://dx.doi.org/10.1590/ S0103-84782001000300030.

Ernani PR, Ribeiro MS, Bayer C. Chemical modifications in acid soils caused by addition of gypsum or limestone. Scientia Agrícola 2001; 58: 825-831. http://dx.doi. org/10.1590/S0103-90162001000400026. 
Freitas CA, Silva CJ, Silva CA, Almeida JÁ, Rincon NS. Addition of agricultural plaster and wood ash to substrate in baruzeiro (Dipteryx alata Vog) seedlings developing. Revista Verde de Agroecologia e Desenvolvimento Sustentável 2015; 10(2): 206-212. http://dx.doi.org/10.18378/rvads. v10i2.2915.

Freitas TAS, Barroso DG, Souza LS, Carneiro JGA. Effect of the roots pruning in the growth of the eucalyptus seedlings. Ciência Florestal 2009; 19(1): 1-6.

Gabriel CA, Cassol PC, Simonete MA, Moro L, Pfleger P, Mumbach GL. Lime and gypsum applications on soil chemical attributes and initial growth of Eucalyptus. Floresta 2018; 48(4): 573-582. http://dx.doi.org/10.5380/ rf.v48i4.57455.

Gazola RN, Buzetti S, Teixeira Filho MCM, Dinalli RP, Moraes MLT, Celestrino TS et al. Doses de N, P and K in the cultivation of eucalyptus in soil originally under Cerrado vegetation. Semina 2015; 1: 1895-1912.

Gelain E, Rosa EJ Jr, Mercante FM, Fortes DG, Souza FR, Rosa YBCJ. Biological nitrogen fixation and leaf nutrient concentration on soybean as a function of molybdenum and gypsum levels. Ciências Agrotecnicas 2011; 35(2): 259269. http://dx.doi.org/10.1590/S1413-70542011000200005.

Hartwig I, Oliveira AC, Carvalho FIF, Bertan I, Silva JAG, Schmidt DAM et al. Associated mechanisms of aluminum tolerance in plants. Semina 2007; 28(2): 219-228.

Industria Brasileira de Árvores - IBÁ. Relatório indústria brasileira de árvores. Brasília, DF; 2016.

Jackson TJ, Burgess T, Colquhoun I, Hardy G. Action of the fungicide phosphite on Eucalyptus marginata inoculated with Phytophthora cinnamoni. Plant Pathology 2000; 49(1): 147-154. http://dx.doi.org/10.1046/j.13653059.2000.00422.x.

Macana YAM. Nutrição e crescimento do eucalipto em resposta a diferentes fontes e métodos de aplicação de cálcio [tese]. Piracicaba: Escola Superior de Agricultura Luiz de Queiroz; 2017.

Marques H, Ferreira CS, Almeida GRR, Cunha LT. Efeito da aplicação de diferentes doses de gesso agrícola em lavouras cafeeiras cultivadas no município de Paraguaçu - MG. Capa 2016; 4(4): 1-14.

Moda LR, Borges BMMN, Flores RA, Santos CLR, Prado RM, Souza JI. Gypsum application in the soybeans notillage system with and without potassium fertilization. Revista Agroambiente Online 2013; 7(2): 129-135.

Nascimento R, Souza JA, Moreira A, Moraes LAC. Phosphogypsum and vinasse application: soil chemical properties and alfalfa productivity and nutritional characteristics. Revista Caatinga 2017; 30(1): 213-219. http://dx.doi.org/10.1590/1983-21252017v30n123rc.

Nietfeld H, Prenzel J. Modeling the reactive ion dynamics in the rhizosphere of tree roots growing in acid soils. I. Rhizospheric distribution patterns and root uptake of $M_{b}$ cations as affected by root-induced $\mathrm{pH}$ and $\mathrm{Al}$ dynamics. Ecological Modelling 2015; 307: 48-65. http://dx.doi. org/10.1016/j.ecolmodel.2015.02.011.

Oliva MA, Barros NF, Souza Gomes MM, Lopes NF. Seca de ponteiros em Eucalyptus camaldulensis Dehn em relação a estresse hídrico e nutrição mineral. Revista Árvore 1989; 13(1): 19-33.

Pauletti V, Pierri L, Ranzan T, Barth G, Motta ACV. Long-term effects of the application of gypsum and lime in a no-till system. Revista Brasileira de Ciência do Solo 2014; 38: 495-505. http://dx.doi.org/10.1590/S010006832014000200014 .

Pinheiro RC, Deus JRJC, Nouvellon Y, Campoe OC, Stape JL, Aló LL et al. A fast exploration of very deep soil layers by Eucalyptus seedling and clones in Brazil. Forest Ecology and Management 2016; 366: 143-152. http:// dx.doi.org/10.1016/j.foreco.2016.02.012.

Rentería-Villalobos M, Vioque I, Mantero J, Manjón G. Radiological, chemical and morphological characterizations of phosphate rock and phosphogypsum from phosphoric acid factories in SW Spain. Journal of Hazardous Materials 2010; 81(1-3): 193-200. http://dx.doi.org/10.1016/j. jhazmat.2010.04.116. PMid:20537794.

Rocha JBO, Pozza AAA, Carvalho JG, Silva CA, Curi $\mathrm{N}$. Effect of liming on the mineral nutrition and initial growth of eucalyptus under field conditions planted in humic Latosol (Oxisol) from Zona da Mata, Minas Gerais State, Brazil. Scientia Florestalis 2008; 36(80): 255-263.

Rocha JHT, Gonçalves JLM, Godinho TO, Souza Filho LFSS. Nutrition and fertilization with sulfur and gypsum application in eucalypt stands. Circular Técnica IPEF 2015; 208:1-14.

Rodrigues FAV, Alvarez VH, Barros NF, Silva IR, Neves JCL. Productivity of eucalypt at 18 months of age, in Cerrado region, in response to application to application of calcium, by lime and to gypsum amendments. Scientia Forestalis 2016; 109: 67-74.

Scanavaca L Jr, Garcia JN. Potencial de melhoramento genético em Eucalyptus urophylla procedente da Ilha Flores. Scientia Forestalis 2003; 64: 23-32.

Sousa DMG, Miranda LG, Oliveira SA. Acidez do solo e sua correção. In: Novais RF, Alvarez VVH, Barros NF, Fontes RLF, Cantarutti RB, Neves JC, editor. Fertilidade do solo. Viçosa: SBCS; 2007.

Stape JL, Binkley D, Ryan MG, Fonseca S, Loos RA, Takahashi EN et al. The Brazil Eucalyptus potential productivity project: influence of water, nutrients and stand uniformity on wood production. Forest Ecology and Management 2010; 259(9): 1684-1694. http://dx.doi. org/10.1016/j.foreco.2010.01.012.

Viera M, Schumacher MV. Contents and input of nutrients in Pinus taeda L. litter related to air temperature and 
rainfall. Revista Árvore 2010; 34(1): 85-94. http://dx.doi. org/10.1590/S0100-67622010000100010.

Vitti GC, Zavaschi E, Moura TA, Gomes MHF. Estudos confirmam os efeitos favoráveis do gesso agrícola na cultura do milho. Visão Agrícola 2015; 13: 49-51.

Wulff-Zottele C, Hesse H, Fisahn J, Bromke M, VeraVillalobos H, Li Y et al. Sulphate fertilization ameliorates long-term aluminum toxicity symptoms in perennial ryegrass (Lolium perenne). Plant Physiology and Biochemistry 2014; 83: 88-99. http://dx.doi.org/10.1016/j.plaphy.2014.07.017. PMid:25123423.

Zandoná RR, Butler AN, Burg GM, Barreto CF, Schimidt MR. Gypsum and lime increase soybean and maize yield and decrease drought stress. Pesquisa Agropecuária Tropical 2015; 45: 128-137. 